\title{
Destinasyon Deneyimi Bileşenleri: Antalya ve İstanbul Destinasyonları Üzerinde Karşılaştırmalı Bir Araştırma ${ }^{1}$
}

\author{
Components of Destination Experience: A Comparative Research on Antalya and İstanbul Destinations
}

\author{
ilker ŞAHIN*, F. Özlem GÜZEL** \\ *Arş.Gör., Akdeniz Üniversitesi Turizm Fakültesi, Dumlupınar Bulvarı, 07058, Kampus Antalya. \\ E-posta: ilkersahin@akdeniz.edu.tr \\ ORCID: 0000-0002-0516-4675 \\ **Doç. Dr., Akdeniz Üniversitesi Turizm Fakültesi, Dumlupınar Bulvarı, 07058, Kampus Antalya. \\ E-posta: ozlemguzel@akdeniz.edu.tr \\ ORCID: 0000-0003-0081-3530
}

MAKALE BILGILERI

Makale işlem bilgileri:

Gönderilme tarihi: 25 Nisan 2017

Düzeltme: 18 Haziran 2017

Düzeltme: 24 Temmuz 2017

Düzeltme: 18 Ekim 2017

Kabul: 24 Ekim 2017

Anahtar sözcükler: Deneyim pazarlamasl, Destinasyon deneyimi, Turist deneyimi, Antalya, İstanbul.

\section{ARTICLE INFO}

Article history:

Submitted: 25 April 2017

Resubmitted: 18 June 2017

Resubmitted: 24 July 2017

Resubmitted: 18 October 2017

Accepted: 24 October 2017

Key words: Experiential marketing, Destination experience, Destination attributes, Tourist Experience.

\section{$\ddot{O Z Z}$}

Destinasyon DNA'larının yapı taşlarını oluşturan ve birbiriyle bağlantılı bütünsel bir yapı haline gelen, mimari, gastronomi, altyapı gibi çeșitli destinasyon deneyimi bileșenleri, turistlerin davranışlarını ve tatil boyunca edindikleri tecrübeleri etkileyebilmektedir. Bu bağlamda destinasyonların deneyimsel bileșenleri konusunda destinasyon yöneticileri ve turizm paydaşları arasında farkındalık yaratarak farklı bakış açıları geliştirmek büyük önem arz etmektedir. Bu araştırmanın temel amacı; (a) destinasyon deneyimini bileşenlerini sahil ve kültür destinasyonları üzerinde karsılaștırmalı ortaya koymak ve (b) bu deneyim bileșenlerine yönelik milliyetler bazında farkılıkları değerlendirmektir. İstanbul ve Antalya destinasyonlarında gerçekleştirilen bu çalışma kapsamında, veri toplama aracı olarak anket tekniğinden faydalanılmıştır. Toplam 1281 yabancı turistin katııımcı olarak yer aldığı araştırmada elde edilen bulgulara göre, destinasyon deneyimi bileșenleri olarak; yerel kültür, aktiviteler, misafirperverlik, altyapı, yenilik fırsatları, hizmet kalitesi, üstyapı estetiği, gastronomi, ulașılabilirlik, fiziki coğrafya, ekonomik değer ve duygular boyutları ortaya çıkmıştır. Bu boyutlardan fiziki coğrafya boyutu İstanbul'da, ulaşım boyutu ise Antalya'da faktörleşmemiştir. İstanbul'un altyapı, hizmet kalitesi ve ulaşım özellikleri, Antalya'nın ise duygular ve ekonomik değer özellikleri konularında Alman turistlere ilișkin algıların İngiliz ve Ruslara göre daha negatif yönlü olduğunu ortaya çıkarmıștır.

\section{Gíriş}

Turizm, temel anlamda ziyaret etme, gezme, görme ve hayatı farklı şekillerde yaşamaya ilişkin çeşitli deneyimlere dayalı bir endüstri (Stamboulis ve Skayannis 2003) olarak düşünüldügün-

\footnotetext{
${ }^{1}$ Bu araştırma, Akdeniz Üniversitesi Bilimsel Araştırma Projeleri Koordinasyon Birimi (BAP) tarafından desteklenmiştir.
}

de turistin bir destinasyonda karşılaştı bir deneyime dönüşmektedir. Destinasyonlar, deneyimlere ev sahipliği yapan ve hatıraların oluştuğu turistik çekim merkezleridir. Her destinasyon, coğrafi, kültürel ve tarihi dokusuyla birlikte ilgili ve destekleyici bileşenlere göre farklı karakterler kazanmaktadır. Bu karakterler doğrultusunda, turistler destinasyonda geçir- 
dikleri tatil süresince bilişsel, duygusal ve fiziksel olarak bir takım deneyim süreçleri içinde yer almakta ve söz konusu sürecin sonunda zaman ve mekân algılarını kaybederek kendilerini içinde bulundukları deneyime kaptırmaktadırlar (Csikszentmihalyi 1975; Normann 1985; Mannell vd. 1998; Edensor 2001; Çetin ve Bilgihan 2014). 21. yüzyılın post-modern turistlerinin gün geçtikçe artan 'farklı olanı deneyimleme' ve 'güzel anılar biriktirme' talebi karşısında, turizm destinasyonlarının sunduğu standart turistik mal ve hizmetlerin, günümüzün deneyimsel beklentilerinin bir miktar gerisinde kaldığı görülmektedir. Bu noktaya dikkat çeken Cohen (1979), turistin yaşadığ 1 destinasyon deneyiminin yalnızca çeşitli turizm hizmetlerinin tüketilmesinden ibaret olmadığını belirtmektedir. Bu bağlamda ziyaret süresi boyunca turistler, destinasyonu bütüncül bir deneyim olarak tüketmektedir (Buhalis 2000; Mossberg 2007). Um ve Crompton'a (1990) göre kişilerin destinasyona ilişkin algıları aslında o destinasyonun sahip olduğu özellikleri nasıl algıladıklarına bağlıdır. Bu bağlamda destinasyonlar, post-modern turistlere neyi sunduklarını analiz ederek, duygusal arayışların dönüşümünde destinasyonlarda deneyim yaratmaya odaklanmalıdırlar. Bu noktadan hareketle bu araştırmanın destinasyon deneyimi bileşenlerine odaklanması, farklı DNA ${ }^{2}$ lara sahip iki turist çekim merkezinin karşılaştırmalı olarak analiz edilmesi ve destinasyon yönetimi konusunda pratik öneriler sunulması bakımından araştırmanın özgün olduğu; bulguların ise turizm deneyimlerine etki eden destinasyon unsurlarına ilişkin mevcut bilgi birikimine ve turizm alanyazınına büyük ölçüde katkı sağlayacağı düşünülmektedir. Çalışma, birbirinden farklı özellikler gösteren, farklı karakterdeki ve stratejik olarak farklı konumlandırılmış iki karakteristik destinasyonda destinasyon deneyiminin nasıl şekillendiğini ve deneyim bileşenlerine ilişkin faktör yapılarının her iki destinasyonda nasıl biçimlendiğini karşılaştırmalı olarak ortaya koymayı amaçlamaktadır.

${ }^{2}$ DNA, destinasyon pazarlamacılarının yerel halk, ziyaretçiler ve potansiyel ziyaretcilerin destinasyonu nasıl algıladıklarını anlamak için kullandıkları öz kimlik öğeleridir (www. destinationthink.com).

\section{DESTINASYON DENEYIMI}

Destinasyonlar, sahip olduğu mevcut sınırları dışından turist çeken çeşitli ürün ve hizmetlerin bir arada sunulduğu bölgelerdir (Pearce 1989). Araştırmalar, bir yandan turizm sektöründe deneyimlere olan talebin oldukça revaçta olduğuna işaret ederken öte yandan günümüz dünyasında turistik destinasyonların deneyimsel özellikleri itibarıyla birbirleriyle kıyasıya bir rekabet içine girdiğine dikkat çekmektedir (Ritchie ve Crouch 2003; Lagiewski ve Zekan 2006; Neuhofer vd. 2012; Çetin ve Bilgihan 2014). Destinasyonu meydana getiren unsurların neler olduğu konusunda alanyazında birbirine benzer nitelikte s1niflamalar bulunmaktadır. Birbirini tamamlayıcı nitelikteki özelliklerin bir araya gelerek turistik destinasyonları oluşturduğu konusunda fikir birliğine varan araştırmacılar turistik destinasyon bileşenlerini tanımlamışlardır. Söz konusu araştırmacıların öncülerinden olan Burkart ve Medlik'e (1992) göre destinasyonlar "çekicilikler, ulaşılabilirlik ve olanaklar" olmak üzere üç temel bileşenden meydana gelmektedir. Dünya Turizm Örgütü'ne (WTO) göre destinasyonun temel bileşenleri çekicilikler, kamu ve özel sektör tesisleri, ulaşılabilirlik, imaj \& nitelik, insan kaynakları ve fiyattır (WTO 2007). Ritchie ve Crouch (2003), turistik destinasyon kaynakları ve çekim unsurları üzerine değerlendirme yaparak yedi kategoriden oluşan bir sınıflama yapmıştır. Bu sınıflamayı bir adım öteye taşıyan Kim (2014), turizm deneyimlerine etki eden destinasyon özellikleri üzerinde bir ölçek geliştirme çalışması yapmıştır. Bu bağlamda destinasyon unsurlarını şu şekilde ifade etmek mümkündür (Buhalis 2000; Ritchie ve Crouch 2003; Ivanovic vd., 2009; Kim 2014): Fiziki coğrafya, kültür ve tarih, aktivite ve etkinlikler, altyapı, üstyapı, paket turlar ve geziler, duyguları hareket geçiren ambiyans, destekleyici hizmetler, gastronomi, misafirperverlik, ulaşılabilirlik, yenilik fırsatları, çevre yönetimi, hizmet kalitesi, destinasyon aidiyeti, ekonomik değer.

Destinasyonların vazgeçilmez unsurlarından biri fiziki coğrafya ve uygun iklim koşullarıdır. Fiziki coğrafya bileşenleri arasında tabiat manzaraları, doğal oluşumlar, dağlar, deniz, kumsallar, fiyortlar, ormanlar, kanyonlar, irmaklar, vadiler, 
patikalar, şelaleler vb. başta olmak üzere birçok doğa harikası yer almaktadır. Ziyaret edilen destinasyonun görülmeye değer ve hayranlık uyandiran tabiata sahip olması, turistlerin tatillerini zenginleştirmekte, onların hafızalarında olumlu anılar birakarak deneyimlerini farklı kılmaktadir (Dwyer ve Kim 2003; Chi ve Qu 2008; Crouch 2011; Kim 2014). Bunun yanı sira post-modern turistler günümüz dünyasında ya da geçmişte başka insanların nasıl bir yaşam tarzına sahip olduğunu merak etmekte; tüm bunları keşfetmek ve deneyimlemek için maceraperest bir anlayışla seyahat etmektedir (Prentice 2001; Page ve Hall 2003). Destinasyonlarda el sanatları, müzikal performans, güzel sanatlar, mimari ve buna benzer öğeler yoluyla ziyaretçilere yerel kültürü deneyimleme fırsatları yaşatılmaktadır. Bölgenin dokusuyla bütünleşen ve yerel özellikler taşıyan bu firsatlar, turistlerin zihninde hatırlanabilirliği tetikleyerek ziyaretçilerin destinasyon deneyimlerini zenginleştirmektedir (Dwyer ve Kim 2003; Kim 2014). Turizm destinasyonunun hatırlanabilirliğini artıran, ziyaretçilerde olumlu duygular uyandıran ve destinasyonun farklı turist tiplerine hitap etmesini sağlayan en önemli özelliklerden biri de ziyaretçilere sunulan çeşitli türde aktivite ve etkinliklerdir. Festival, konserler, turlar, şölen, kongre, şampiyona, olimpiyat, forum vb. etkinlikler, insanların günlük yaşamın rutin aktivitelerinden bir süreliğine uzaklaşarak kaçış fırsatı elde etmelerini sağlamaktadır (Pine ve Gilmore 1999; Dwyer vd. 2000; Dwyer ve Kim 2003; Kim 2014). Ayrica turistler, destinasyonları ziyaretleri esnasında yörede yaşayan yerel halk ile birebir temas kurmaktadır. Bu bağlamda yerel halk ve gösterilen misafirperverlikte önemli bir deneyim bileşenine dönüşmektedir. Bilmediği bir destinasyonu ziyaret eden bir turist, ziyaret noktalarına ulaşım için yol tarifi, uygun konaklama ve yeme-içme hizmetlerine erişim başta olmak üzere hemen hemen her konuda bilgiye ihtiyaç duymaktadır. Hakkında çok az bilgi sahibi olduğu bir yerde bilgi arayışında olan turistin yardım isteyeceği ilk kişilerin başında yerel halka mensup insanlar gelmektedir. Yerel halk ile iletişim kuran ve karşılığında sıcak ilgi ve yardımsever tavırlar gören bir turist, bölge halkının oldukça samimi ve misafirperver insanlardan oluştu- ğu algisına kapılacaktır (Machlis ve Burch 1983; Driscoll vd. 1994).

Araştırmacılar, bir ülkenin altyapı imkânlarının, turizm destinasyonunun çekiciliğini belirleyen ve turistik mal ve hizmetlere erişimi kolaylaştıran en önemli unsurların başında geldiğini belirtmektedir (Chew 1987; Gunn 1988; Inskeep 1991; Sakai 2006). Ritchie ve Crouch (2003), turist hizmetleri sürecinde turizm destinasyonlarının eskisi gibi pasif bir rolle yetinmediğini, rekabet gücünü artırmak için stratejik pazarlama modellerine odaklandığını belirtmektedir. Rekabetçi koşullara ayak uyduran destinasyonlarda turist enformasyon ofisleri, kongre ve ziyaretçi büroları, yerel veya ulusal turizm kuruluşları, ekonomik gelişim ajansları açılmakta, bununla birlikte kamu güvenliği, posta ve kargo hizmetleri, sağlık hizmetleri ve eğitim sistemleri, perakendecilik, engellilere yönelik hizmetler vb. unsurların geliştirilmesine özen gösterilmektedir (Ritchie ve Crouch 2003). Ayrica altyapiya paralel olarak turistlerin bölgeye erişimini sağlayan ulaşılabilirlik, destinasyon özelliklerinin olmazsa olmazlarından biri olarak önemli bir rol üstlenmektedir. Kolay ve kaliteli ulaşım imkânlarına sahip destinasyonlarda hatırlanabilir deneyimleri destekleyerek tatil deneyiminin pozitif yönde etkilemesi, çekiciliklerin meydana getirilmesi ve bunların kusursuz bir şekilde sürdürülebilmesi mümkündür (Kaul 1985; Driscoll vd. 1994; Buhalis 2000; Dwyer ve Kim 2003; Khadaroo ve Seetanah 2008). Altyapının ve ulaşılabilirliğin yanı sıra üstyapı özellikleri de destinasyon deneyimini zenginleştirmektedir. Mossberg (2007) otel dizaynı, restoran tasarımı/iç mimarisi ve insan yapımı olan çekiciliklerin üstyapıya örnek teşkil ettiğini belirtmektedir. Bu durum Pine ve Gilmore'un (1998) 'estetik deneyim' boyutuna karşılık gelirken Schmitt'in (1999) ise duyusal modül kapsaminda değerlendirilmektedir. Oral ve Çelik'in (2013) tur operatörlerinin turistlere sundukları ürünlerin estetik değerine yönelik yaptıkları araştırmada, destinasyondaki estetik değerler ile tatmin arasında olumlu ilişki gözlenmiştir. Elde edilen bulgular bize destinasyonda yer alan üstyapı bileşenlerine ilişkin genel mimari, tasarım, dekor gibi özelliklerin turistlerin estetik anlayış- 
ları ve beklentileriyle uyumlu olması gerektiği konusunda ipuçları vermektedir. Turistler tatilleri süresince görsel açıdan güzel olarak algıladıkları yapıları ziyaret etmekten ve onları fotoğraflamaktan zevk duymakta ve görsel tatmin sağlamaktadır.

Destinasyon deneyiminde bir diğer önemli boyut, hizmet kalitesidir. Turistler, hizmetin üretim ve tüketim süreçlerinde firmalar ile temas halindedir. Dolayısıyla turistler, sunulan hizmetin kalitesini kendilerine göre değerlendirme olanağına sahiptirler ve tatillerine anlam katan, tatil deneyimini zenginleştiren kaliteli hizmet almayı istemektedirler (Pine ve Gilmore 2000; Go ve Govers 2000; Murphy vd. 2000; Kandampully 2000). Bu sebeple hizmet kalitesi destinasyonda yaşanan toplam turizm deneyimi içinde kritik ve önemli bir yer edinmiş; bununla birlikte turizm işletmelerinin ne derece başarılı olduklarını ortaya koymaya başlamıştır. Bu çerçevede alanyazın incelendiğinde, yüksek hizmet kalitesi sunan turizm destinasyonlarının turistlere tatminkâr ve eğlenceli deneyimler yaşatması ve böylelikle pazardaki rakipleri arasında fark yaratması mümkün görünmektedir (Otto ve Ritchie 1996; Kim 2014). Destinasyonun özelliklerden biri de algilanan ekonomik değer (fiyat-değer) unsurudur. Bu durum ekonomi terminolojisinde sıkça kullanılan fiyat-performans oranıdır. Bu özellik turistlerin destinasyonu fiyat ve değer açısından değerlendirmesiyle ilgili bir durumdur. Turistlerin destinasyonu ziyaret etmek uğruna yaptıkları masrafların, sarf ettikleri eforun ve harcadıkları toplam paranın yaşamış oldukları destinasyon deneyimine değer olduğunu düşünmeleri hem destinasyon imajına hem de hatırlanabilirliğine olumlu yönde etki edeceği öngörülmektedir (Driscoll vd. 1994; Kozak 2001; Dwyer ve Kim 2003; Chi ve Qu 2008).

Günümüz turistleri sıradanlaşmış tekdüze bir tatil geçirmek yerine, farklı anılar yaşamayı tercih etmektedir. Cohen'e (1979) göre turist, fitratında yenilik arayışını barındıran; bu yenilikten ve belki de bir daha aynısını yaşayamayacağı bir tatilden elde ettiği eşsiz deneyimden haz duyma beklentisiyle yolculuk yapan bir seyyah gibidir. Yenilik kavramından kastedilen kişinin yaşamı- na eşsiz ve daha önce tecrübe etmediği farklı bir deneyim getirmektir. Lee ve Crompton (1992) yenilik algısının miktarı, destinasyondaki tarihi kalıntılar, kültürel atmosfer, çevre, yerel halk ve diğer ziyaretçilerle ilişkili olarak değişebileceği görüşünü ortaya atmaktadır. Söz konusu görüşler 1şığında bir bütün olarak düşünüldüğünde destinasyonların ziyaretçilerine yenilik fırsatları sunma (novelty) fikri turizm sektöründe 'eşsiz deneyimler yaratma' girişiminden kaynaklanmaktadır. Destinasyonda yenilik ile paralel olarak ele alınabilecek olan bir diğer boyut ise destinasyonun tetikleyeceği ve turiste yaşatacağ $\mathrm{duy}-$ gulardır. Cohen'e (1979) göre turistler, günlük rutinden geçici bir süreliğine uzaklaşıp kendileri için daha anlamlı deneyimler yaşayabilecekleri herhangi bir yere seyahat etme eğilimi göstermektedirler. Boorstin (1964) ve MacCannell'e (1973) göre ise insanlar, monoton hayatlarında her gün aynı ya da benzer şeylerle zaman geçirmektedir. Bu tekdüze bir yaşamlarına bir renk katmak amaciyla insanlar zaman zaman otantik farklı ülke ve kültürlere seyahat etme ihtiyacı hissederek daha tatmin edici bir yaşam biçimine yönelmektedir. Destinasyonun sunduğu olanaklar böylelikle kişinin olumlu duygular yaşamasına ve kendini iyi hissetmesine yol açabilmektedir. Alanyazın taramasında görüldüğü üzere destinasyon deneyimi bileşenleri çok boyutlu düşünülmelidir. Destinasyon deneyimi bileşenlerinin ortaya çıkarılması turistlerin destinasyon seçim kararlarını yönlendirmek, tatil deneyimi memnuniyetlerini ve tatil sonrası davranışlarını etkileyebilmek açısından önem arz etmektedir.

\section{YÖNTEM}

Karşılaştırmalı olarak destinasyonların deneyimsel bileşenlerini ortaya koymak amaciyla nicel araştırma yöntemi esas alınmış; veri toplama aracı olarak ise anket tekniğinden faydalanılmıştır. Destinasyon deneyimi bileşenlerine yönelik soru formunda kullanılan ifadelerin büyük bir bölümü Kim (2014) tarafından geliştirilen 'Hatırlanabilir Turizm Deneyimlerini Etkileyen Destinasyon Özellikleri Ölçeği'nden uyarlanmıştır. Diğer ifadeler ise Lee ve Crompton (1992); Driscoll vd. (1994); Tribe ve Snaith (1998); Pine ve Gil- 
more (1998); Kozak (2001); Fields (2002); Dwyer ve $\mathrm{Kim}$ (2003); Kivela ve Crotts (2005, 2006); Oh, Fiore ve Jeoung (2007); Feng ve Jang (2007); Chi ve $\mathrm{Qu}$ (2008); Zhang ve Chow (2008) tarafından yapılan çalışmalardan yararlanılarak oluşturulmuştur. Kültürel geçerliliği uzmanlar tarafından yapılan ölçek, anadili Rusça ve Almanca olan eğitmenler tarafından yabancı dillere çevrilmiştir. Daha sonra farklı uzman kişilerce İngilizceden Rusça ve Almancaya yapılan çeviriler tekrarlanmış ve bu sayede üç dilde de aynı anlamı veren ifadeler elde edilmiştir. Çalışma kapsamında 5'li Likert tipi ölçek kullanılmıştır (1-Kesinlikle Katılmıyorum, 5-Kesinlikle Katılıyorum). Araştırma sahası olarak ise İstanbul ve Antalya destinasyonları tercih edilmiştir. Bu tercihin birincil nedeni destinasyon deneyimi bileşenlerini sahil ve kültür destinasyonları üzerinde karşılaştırmalı olarak ortaya koymaktır. Bununla birlikte, İstanbul ve Antalya'nın Kültür ve Turizm Bakanlığı istatistiklerine göre 2015 yılı yaz döneminde en fazla turist çeken destinasyonlar olması bu tercihi destekler niteliktedir. Kültür ve Turizm Bakanlığı Yatırım İşletmeleri Genel Müdürlüğü tarafından açıklanan istatistiklere göre, 2015 yaz sezonunun Haziran, Temmuz ve Ağustos aylarında Antalya'yı 5,436,426; İstanbul'u ise $3,829,799$ yabancı turist ziyaret etmiştir. Bu aylarını kapsayan yaz turizm sezonu baz alındığında, bu dönem içinde ülkemizi ziyaret eden turistlerin \%37'sinin Antalya, \%26'sının ise İstanbul'a geldiği görülmektedir. Anketler, turizm sezonu boyunca, destinasyonların önemli ziyaret noktalarında (Sultanahmet Meydanı, Hipodrom Meydanı, Ayasofya Müzesi ve Topkapı Sarayı çevresi, Kaleiçi, Saat Kulesi çevresi, Cumhuriyet Meydanı, Antalya Yat Limanı, Konyaaltı Sahili), havalimanlarında, günlük turlarda (Kemer, Belek, Alanya, Side) ve otellerde uygulanmıştır. 134 örneklem üzerinde gerçekleştirilen pilot çalışma sonrasında net anlaşılmadığ ler üzerinde düzeltme yapılmıştır. Araştırmanın evrenini, 2015 y1lı yaz turizm sezonunda Antalya ve İstanbul destinasyonunu bireysel veya paket tur organizasyonu ile ziyaret eden; ağırlığı Rus, Alman ve İngilizlerden oluşan farklı milliyetlere mensup yabancı turistler oluşturmaktadır. Araştırma kapsamında tesadüfî olmayan örnekleme yöntemi kullanılmıştır. Bu amaçla “Destinasyonda minimum üç gün geçirmiş" olma şartını taşıyan turistlerin araştırmaya dâhil edilmesine özen gösterilmiştir. Katılımcılar, yargısal örnekleme yöntemi ile seçilmiştir. Raosoft yazılımı \%95 güven düzeyinde minimum örneklem miktarı olarak 385 örnekleme ulaşılması gerektiği sonucunu ortaya çıkarmıştır. Yazılım hesaplamalarına uygun olarak 687'si İstanbul, 594'ü ise Antalya'da olmak üzere toplam 1281 yabancı turiste anket uygulanmiştır.

\section{BULGULAR}

Katılımcıların demografik özelliklerin belirlenmesi amacıyla yapılan Frekans Analizi sonuçları her iki destinasyonda da toplam kadın katılımc1 sayısınin (n:690) erkeklere oranla (n:591) daha fazla olduğunu göstermektedir. Yaş dağılımına ilişkin veriler incelendiğinde oldukça genç bir turist profili elde edildiği dikkat çekmektedir. Bulgulara göre İstanbul'u ziyaret eden katılımcıların büyük oranda $(\% 62,9)$ internet ve sosyal medya kullanıcısı olduğu; İstanbul hakkında bilgi edinme aracı olarak internetten faydalandıkları ortaya çıkmıştır. Bilgi kaynağı olarak internet $(\% 34,5)$ ve seyahat acentelerini $(\% 34,8)$ kullanan Antalya ziyaretçilerine ilişkin oransal dağglımın birbirine oldukça yakın olduğu gözlenmektedir.

Destinasyon özelliklerinin hangi faktörlerden meydana geldiğini ortaya koymak amaciyla, araştırmada yer alan toplam 41 ifadenin, Varimax döndürme yöntemi yardımıyla Açımlayıcı Faktör Analizine (AFA) tabi tutulmasına karar verilmiştir. Araştırma kapsamında anket uygulamas1nın gerçekleştirildiği turizm destinasyonuna göre farklı faktör yapılarının ortaya çıkıp çıkmadığını tespit etmek maksadıyla İstanbul ve Antalya için ayrı ayrı AFA analizleri gerçekleştirilmiştir. Bu sayede faktörlerde ortaya çıkan bölgesel farklilıklar incelenerek net bir faktör yapılarının elde edilmesi amaçlanmıştır. İlk adım olarak açımlayıcı faktör analizine dâhil edilmesi planlanan ifadelerin normal dağılım varsayımını sağlayıp sağlamadığı incelenmiştir. İ́adelerin çarpıklık ve basıklık katsayıları dikkate alınmış ve dağılımın $-1,96$ ila $+1,96$ arasında değerler sergilediği gözlenmiştir. Buna göre söz konusu ifadelerin tama- 
mında normal dağılım varsayımının karşılandığı görülmüş̧ür. AFA neticesinde elde edilen değerler Tablo 1'de gösterilmektedir. Değişkenler arasındaki ilişkiyi ortaya koymak üzere ise Bartlett Küresellik Testi'nden yararlanılmıştır. Öte yandan ölçek güvenirliklerinin test edilmesi amacıyla Crobach's Alpha katsayıları incelenmiştir. Tablo 1'de yer alan değerler incelendiğinde, ilk aşamada gerçekleştirilen iki AFA analizinde de Bartlett Küresellik Testine göre anlamlılığın ",000" değerinde olduğu görülmektedir. Bu sonuç faktör analizinde yer alan ifadelerin birbiriyle ilişkili olduğuna işaret etmektedir. Her bir faktörün içsel tutarlılıkları için hesaplanan Cronbach's Alpha değerlerinin " 0,57 " ile " 0,84 " arasında değissen değerler aldığ 1 ve birkaç faktörün içsel güvenirliğinin düşük olduğu görülmüştür. Nunnally (1978) 0,70 ve üzeri Cronbach katsayısının iyi düzeyde içsel güvenirliğe işaret ettiğini ancak konu bakımından gelişim sürecinin ilk aşamalarında olan araştırmalarda 0,50-0,60 arasındaki güvenirlik katsayısının kabul edilebilir olduğuna dikkat çekmektedir. Shoukri ve Edge (1996) ise 0,40-0,75 arası değerin iyi uyuma işaret ettiğini vurgulamaktadır. Araştırmanın karşılaştırmalı analiz yaklaşımı sergilemesi, odaklandığı konunun gelişim sürecinde olması ve ilgili referans değerleri dikkate alındığında tatminkâr düzeyde içsel güvenilirliğinin sağlandığı kabul edilmiştir. AFA ilk olarak İstanbul destinasyonu için uygulanmıştır. Tablo 1 incelendiğinde İstanbul için 0,90 Cronbach Alpha katsayısına ulaşıldığı görülmektedir. Bu sonuç ölçeğin yüksek düzeyde güvenilir olduğuna işaret etmektedir.

AFA analizleri sonucunda elde edilen KMO değerleri $(0,882)$ incelendiğinde örneklem say1sının faktör analizi yapmak için yeterli olduğu sonucunu ortaya koymaktadır. KMO değerleri değişkenlerin yeterli korelasyona sahip olduğunu ve ortak faktörü paylaştığını göstermektedir. İstanbul için gerçekleştirilen AFA'da eş kökenliği 0,50'nin altında olan üç ifade analizden çıkarılmıştır. Ardından, boyutların hiçbirinde 0,40'ın üzerinde faktör yükü elde edemeyen bir ifade daha analizden çıkarılarak analizin anlamlılı̆̆ arttırılmaya çalışılmıştır. İstanbul destinasyonuna yönelik gerçekleştirilen analiz sonuçları 11 faktör grubu altında toplamda 34 değişkenden oluşan yapının toplam varyansının $\% 62$ oranında olduğuna işaret etmektedir.

İkinci AFA, Antalya destinasyonu için uygulanmıştır. Tablo 1 incelendiğinde Antalya için 0,92 değerinde Cronbach Alpha katsayısına ulaş1ldığ 1 ve ölçeğin yüksek düzeyde güvenilir olduğu ortaya çıkmıştır. Elde edilen KMO değerleri $(0,897)$ incelendiğinde ise örneklem sayısının faktör analizi yapmak için yeterli olduğu sonucunu ortaya koymaktadır. Dolayısıyla bu destinasyonda da ortaya çıkan KMO değerleri değişkenlerin yeterli korelasyona sahip olduğunu ve ortak faktörü paylaştığını göstermektedir.

Antalya için uygulanmış ve eş kökenliği 0,50'nin altında olan bir ifade analizden çıkarılmıştır. Ardından, 0,40'ın üzerinde faktör yükü elde edemeyen ve benzer faktör yüküyle birden fazla boyut altında toplanan üç ifade daha analizden çıkarılmıştır. Anlamlı bir dağılım elde etmek amaciyla, 41 ifadenin 36 tanesi analize dâhil edilmiştir. Antalya'ya ilişkin analiz sonuçları 11 faktör grubu altında toplamda 37 değişkenden oluşan yapının toplam varyansının $\% 69$ oranında olduğunu göstermektedir (Tablo 1). İki destinasyon karşılaştırıldığında, İstanbul'un toplam yedi faktörde Antalya'dan daha yüksek ortalamalar elde edildiği görülmektedir. Yerel kültür, aktiviteler, gastronomi, fiyat-değer, duygular olarak isimlendirilmiş olan beş faktörde İstanbul daha yüksek ortalamalara ulaşmış olmasına rağmen, bu farkın çok yüksek düzeyde olmadığı görülmüştür. Öte yandan misafirperverlik (ort:4,1) ve altyap1 (ort:3,6) boyutlarında her iki destinasyonun aynı ortalamalar elde ettiği göze çarpmaktadır. Dikkat çeken bir diğer unsur ise İstanbul'un, üstyapı estetiği faktöründe Antalya'ya oranla daha olumlu bir ziyaretçi algısına sahip olmasıdır. Her iki destinasyonun 'üstyapı estetiği' faktörlerine ilişkin ortalamalar kıyaslandığında aradaki farkın 0,7 puan olduğu ve İstanbul'un üstyapı estetiğine iliş̧kin ziyaretçi algısı konusunda Antalya'ya göre daha üstün bir performans ortaya koyduğu ortaya çıkmıştır. Buna karşın Antalya'da turistlerin hizmet kalitesi algısı, İstanbul'a oranla daha olumlu yöndedir.

Araştırma kapsamında destinasyon bileşenlerine ilişkin algıların turistlerin milliyetlerine göre 
Tablo 1. Destinasyonlara İlişkin AFA Sonuçları

\begin{tabular}{|c|c|c|c|c|c|c|c|c|}
\hline Faktörler ve Iffadeler & \multicolumn{2}{|c|}{ Faktör Yükü } & \multicolumn{2}{|c|}{ Öz Değer } & \multicolumn{2}{|c|}{ Açıklanan Varyans (\%) } & \multicolumn{2}{|c|}{ Cronbach Alpha $(\alpha)$} \\
\hline Ortalama İst/Ant & $\dot{I} s t$ & Ant & $\dot{I} s t$ & Ant & $\dot{I} s t$ & Ant & Ist & Ant \\
\hline Faktör 1: Yerel Kültür & & & 1,25 & 1,58 & 4,91 & 6,23 & ,61 & ,77 \\
\hline Yerel yaşam tarzını deneyimleme & ,74 & ,73 & & & & & & \\
\hline Gezi programları ve rehberli turlar &, 59 & ,77 & & & & & & \\
\hline Yerel kültürü deneyimleme & ,70 & ,75 & & & & & & \\
\hline Faktör 2: Aktiviteler & & & 1,00 & 1,69 & 3,91 & 6,73 & ,54 & 78 \\
\hline Spor ve rekreasyon imkanları &, 50 & 67 & & & & & & \\
\hline Sıra dişı aktiviteler & 74 & 77 & & & & & & \\
\hline İlgi çeken aktiviteler & 60 & 74 & & & & & & \\
\hline Gece hayatı ve akşam aktiviteleri & 71 & 52 & & & & & & \\
\hline Zengin alışveriş imkânları & 47 & 67 & & & & & & \\
\hline Faktör 3: Misafirperverlik & & & 2,18 & 1,22 & 6,96 & 5,69 & 82 & 75 \\
\hline Sicakkanlı yerel halk & 81 & 79 & & & & & & \\
\hline Yardımsever yerel halk & 85 & 85 & & & & & & \\
\hline Bildiklerini paylaşan yerel halk & 73 & .64 & & & & & & \\
\hline Faktör 4: Altyapı & & & 1,70 & 1,23 & 6,51 & 5,76 & 69 & 73 \\
\hline İyi tasarlanmış ve kaliteli altyapı & 40 & ,58 & & & & & & \\
\hline Yön işaretleri ve levhaların yeterliliği & 62 & 81 & & & & & & \\
\hline Kolay ulaşlır turizm enformasyon ofisleri & .64 & ,76 & & & & & & \\
\hline Faktör 5: Yenilik Fursatları $\quad(4,4 / 3,9)$ & & & 1,89 & 1,45 & 6,75 & 6,16 & 83 & 83 \\
\hline Sıra dışı deneyim fırsatları & ,76 & ,70 & & & & & & \\
\hline Yeni deneyim fırsatları & 82 & 81 & & & & & & \\
\hline Yeni keşifler yapma fırsatları & ,78 & ,75 & & & & & & \\
\hline Faktör 6: Ulaşım & & & 1,29 & --- & 4,96 & --- & ,57 & --- \\
\hline Turistik yerlere kolay ulaşım & 64 & --- & & & & & & \\
\hline Destinasyona ulaşımın kolaylığı & ,63 & --- & & & & & & \\
\hline Destinasyon içi kolay ulaşım/toplu taşıma & ,76 & --- & & & & & & \\
\hline Faktör 7: Hizmet Kalitesi $\quad(3,8 / 4,0)$ & & & 1,06 & 1,37 & 4,41 & 5,79 & ,74 & ,74 \\
\hline Kibar ve sıcakkanlı personel & 48 & 73 & & & & & & \\
\hline Kişiselleştirilmiş hizmet &, 55 & 80 & & & & & & \\
\hline Üst düzey hizmet kalitesi &, 53 & 76 & & & & & & \\
\hline Faktör 8: Üstyapı Estetiği & & & 1,37 & 1,18 & 5,50 & 8,53 & 70 & ,70 \\
\hline İlginç yapılar & 72 & 72 & & & & & & \\
\hline Güzel şehir mimarisi & ,77 & 82 & & & & & & \\
\hline Estetik mimari yapılar & 71 & 80 & & & & & & \\
\hline Faktör 9: Gastronomi & & & 1,17 & 1,08 & 4,87 & 5,68 & ,62 & 62 \\
\hline Türk mutfağını deneyimleme & 47 & 65 & & & & & & \\
\hline Dünya mutfaklarını deneyimleme & ,76 & 82 & & & & & & \\
\hline Farklı gastronomik deneyim olanakları & 75 & ,74 & & & & & & \\
\hline Faktör 10: Ekonomik Değer $\quad(3,8 / 3,7)$ & & & 1,54 & 2,68 & 6,17 & 6,81 & ,76 & ,76 \\
\hline Ekonomik yiyecek \& konaklama fiyatları & 81 & ,75 & & & & & & \\
\hline Ekonomik giriş ücretleri/etkinlik biletleri & 81 & 80 & & & & & & \\
\hline Ekonomik değer & 70 & 75 & & & & & & \\
\hline Faktör 11: Duygular & & & 8,58 & 2,11 & 7,34 & 6,73 & ,79 & ,79 \\
\hline İyi duygular uyandıran atmosfer &, 54 & 44 & & & & & & \\
\hline Büyüleyici destinasyon deneyimi &, 57 & 45 & & & & & & \\
\hline Rutin hayattan uzaklaşma & ,71 & ,73 & & & & & & \\
\hline Farklı bir zaman/mekân algısı yaratma & 65 & 70 & & & & & & \\
\hline Rahatlatan destinasyon deneyimi & 75 & 68 & & & & & & \\
\hline Faktör 12: Fiziki Coğrafya & & & --- & 1,00 & --- & 5,09 & --- & 70 \\
\hline Büyüleyici ve etkileyici manzaralar & --- & 83 & & & & & & \\
\hline Güzel hava ve iklim & --- & 79 & & & & & & \\
\hline Farklı ekolojik alanlar & --- & ,73 & & & & & & \\
\hline $\begin{array}{l}\text { İstanbul: KMO: 0,882; Bartlett's Test: 8293,10 } \\
\alpha: 0,90 ; \text { Varyans Aç1klama: } \% 62,34\end{array}$ & 0,000 & $\begin{array}{l}\text { Anta } \\
\text { Vary }\end{array}$ & $\mathrm{KM}$ & 0,897 & $\begin{array}{l}\text { Bartlett } \\
69,25\end{array}$ & 9737,6 & o: 0,0 & \\
\hline
\end{tabular}


anlamlı bir farklılık gösterip göstermediğini ortaya koymak amacıyla tek yönlü Manova analizinden yararlanılmıştır. Öncelikle analiz kapsamında varyansların eşitliği varsayımının sağlanıp sağlanmadığını tespit etmek amaciyla Levene Testi'nden yararlanılmıştır. Levene Testi sonuçları 0,05'in üzerinde anlamlılık değeri elde eden değişkenler (Altyapı, Ulaşım, Hizmet Kalitesi, Duygular) tespit edilmiştir. Analiz neticesinde ortaya çıan $p$ değerleri varyansların eşitliği varsayımının sağlandığını göstermektedir ( $p>0,05)$. Gruplar boyunca değişkenler arasında korelasyonun eşit olduğu varsayımını test etmek amacıyla ise Box's M Testi'nden faydalanılmıştır. Levene Testi neticesinde 0.05 'den düşük $p$ değeri elde eden ve milliyetler arası anlamlı farklılık göstermeyen değişkenler analizden çıkarılarak test bir kez daha tekrarlanmıştır. Box's M Testi sonucunda elde edilen anlamlılık değerinin (sig. $=0,103$; sig $=0,102)$, minimum değer olarak kabul edilen 0,05 'ten büyük olduğu görülmüştür. Öte yandan Huberty ve Petoskey'e (2000) göre p değerinin 0,005 'den büyük olması değişkenler arasında korelasyonun eşit olduğuna işaret etmektedir. Bu bilgiler 1şığında p değerinin her iki referans düzeyinin üstünde olduğu görülmüş ve gruplar boyunca değişkenler arasında korelasyonun eşit olduğu varsayımının sağlandığı kabul edilmiştir (İstanbul: Box's M:29,032; p=0,103>0,05; Antalya: Box's M:30,267; $\mathrm{p}=0,073>0,05$ ).

Wilks' Lambda Testi sonucunda elde edilen anlamlılık değerleri $(\mathrm{p}<0,05)$ İstanbul ve Antalya destinasyonlarına ilişkin deneyim bileşenleri arasında turistlerin milliyetlerine göre anlamlı bir farkın var olduğuna işaret etmektedir (İstanbul: Wilks Lambda $(\lambda)=0,816 ; \mathrm{F}=6,301 ; \mathrm{p}<, 001$; Antalya: Wilks Lambda $(\lambda)=0,905 ; \mathrm{F}=7,490 ; \mathrm{p}<$ ,001). Farkın hangi milliyetler arasında gerçekleştiğini ortaya koymak amacıyla çoklu karşılaştırmalara imkân veren ve yaygın Post-Hoc uygulamalarından olan Tukey Testi'nden faydalanılmıştır. Tukey Testi sonuçları İstanbul'un ziyaretçilerine sunduğu "altyapı, ulaşım, duygular ve hizmet kalitesi" faktörlerinde Alman turistlere ait ortalamaların, İngiliz ve Ruslara göre istatistiksel olarak anlamlı derecede farklı olduğunu göstermektedir. Bulgulara göre İstanbul'un altyapı olanakları konusunda Almanlar $(3,3)$, İngiliz $(3,8)$ ve
Ruslara $(4,0)$ göre daha düşük ortalamalara sahiptir. Başka bir ifadeyle Almanlar, İstanbul destinasyonun sahip olduğu altyapı imkânlarının yeterli olduğu düşüncesini desteklememektedir. Öte yandan İstanbul'un altyapı imkânları konusundaki Rus turistlerin algıları Alman ve İngilizlere göre bir miktar daha olumlu yöndedir. İstanbul'un ulaşım olanakları konusunda ise İngilizler ve Rusların Almanlara göre daha olumlu düşünceye sahip oldukları ortaya çıkmıştır. İngilizler İstanbul'un ulaşım olanaklarını ve sunulan hizmet kalitesini nispeten yeterli $(4,0)$ bulurken aynı durum Almanlar $(3,6)$ için söz konusu değildir. Bulgular İstanbul'u ziyaret eden Almanların destinasyonun kendilerine sunduğu altyapı ve ulaşım imkânları ile hizmet kalitesinin yeterli olduğu fikrini desteklemediklerini ve nötr bir düşünce ortaya koyduklarını göstermektedir. Elde edilen bulgulara dayanarak Alman turistlerin söz konusu hususlarda İngiliz ve Ruslara göre daha olumsuz bir algıya sahip oldukları söylenebilir. Buna göre Almanların İstanbul'un ulaşım, altyapı ve hizmet kalitesinin yeterliliği konusunda çekimser oldukları sonucuna ulaşılabilir.

MANOVA kapsamında İstanbul'a yönelik gerçekleştirilen işlem basamakları Antalya destinasyonu için tekrarlanmıştır. Antalya destinasyonunda Levene Testi neticesinde ' 0,05 'in üzerinde değer elde eden faktörler (Hizmet Kalitesi, Duygular, Ekonomik Değer, Misafirperverlik) analize dâhil edilmiştir. Sonuçlar Antalya'da destinasyon deneyimi bileşenlerine ilişkin algıların milliyetlere göre istatistiksel olarak anlamlı bir farklılık sergilediğini ortaya koymuştur. Bulgular duygular ve ekonomik değer değişkenlerinde milliyete göre anlamlı bir farkın varlığına işaret etmektedir. Misafirperverlik ve hizmet kalitesi hususlarında söz konusu üç milliyete ait ortalamalar 4,00 ve üzeri değerler elde etmiş ve Manova analizi kapsamında istatistiksel olarak anlamlı bir sonuç ortaya çıkarmamıştır. Elde edilen sonuçlar değerlendirildiğinde Almanların Antalya destinasyonuna ilişkin ekonomik değer algısının İngiliz ve Rus turistlere daha negatif yönlü olduğu (ort: 3,5) anlaşılmaktadır. Bu bulgu Antalya'yı ziyaret eden Alman turistlerin, destinasyonun ekonomik değerinin yüksek olduğu düşüncesini destekleme konusunda çekimser olduklarının gösterge- 
sidir. Buna karşın Ruslar Antalya'nın ekonomik değerinin yüksek olduğu düşüncesini desteklemektedir. Benzer durumun duygular faktörü konusunda da ortaya çıktığ 1 dikkat çekmektedir. Analiz sonuçları, İngiliz $(4,0)$ ve Rusların $(4,2)$ Alman turistlere $(3,8)$ göre Antalya destinasyonunun ziyaretçilerde olumlu duygular uyandırdığı görüşünü daha fazla desteklediğini göstermektedir. Bu sonuçlardan hareketle, Antalya'yı ziyaret eden İngiliz ve Rus turistlerin pozitif duygular ile ekonomik değer konusundaki algılarının Almanlara göre daha olumlu yönde olduğu söylenebilir. Analiz neticesinde Antalya destinasyonunda sunulan hizmet kalitesi ve yabancilara karşı gösterilen misafirperverlik konularında ise üç milliyete ait algıların olumlu yönde olduğu ve katılımciların söz konusu hususlarda 4,0 ve üzeri ortalamalar sergilediği görülmüştür.

\section{SONUÇ}

Araştırma kapsamında her iki destinasyon için ayrı olarak gerçekleştirilen Açımlayıcı Faktör Analizi (AFA) neticesinde toplam 11 faktörlü bir yapı elde edilmiştir. Ortaya çıkarılan 11 faktörün 10 tanesinin her iki destinasyonda da ortak olduğu bulgusuna ulaşılmıştır. Söz konusu ortak faktörler literatüre paralel olarak aşağ1daki gibi isimlendirilmiştir: "Yerel Kültür'; 'Aktiviteler'; 'Misafirperverlik', 'Altyap1'; 'Yenilik Frrsatları'; 'Hizmet Kalitesi'; 'Üstyapı Estetiği'; 'Gastronomi'; 'Fiyat ve Değer', 'Duygular.' Buna karşın 'Fiziki Coğrafya' boyutunun yalnızca Antalya; 'Ulaşım' boyutunun ise sadece İstanbul destinasyonunda ortaya çıktığı ve faktörleştiği görülmüştür. Başka bir ifadeyle İstanbul'da 'Fiziki Coğrafya' boyutunun yerine 'Ulaşım; Antalya'da ise 'Ulaşım' boyutunun yerine 'Fiziki Coğrafya' faktörünün ortaya çıktığını söylemek mümkündür. İstanbul destinasyonunda ortaya çıkan destinasyon deneyim bileşenlerine yönelik faktörlerin ortalama sonuçları değerlendirildiğinde İstanbul'da sırasıyla "üstyapı estetiği, yenilik firsatları ve duygular" boyutları ön plana çıkmaktadır. Üst yapı estetiğinin destinasyon deneyimi bileşeni kapsamında İstanbul'da öne çıkması İstanbul tanıtımında şehir mimarisinin (Bizans, Osmanlı ve aynı zamanda modern ya- pılarının) ön plana çıkarılması gerektiğini ortaya çıkarmaktadır. Günümüz turistleri artık sıradanlaşmış tekdüze bir tatil geçirmek yerine, yenilik arayışının peşinde farklı ve sıradışı deneyimleri yaşamayı tercih etmektedir. Ortaya çıkan bu yeni anlayış, turistlerin seyahat motivasyonlarını büyük ölçüde etkilemekte ve destinasyon seçim sürecinde ve tatmininde kilit rol oynamaktadir. Nitekim Cohen de (1979) turisti, fitratında yenilik arayışını barındıran; bu yenilikten ve belki de bir daha aynısını yaşayamayacağı bir tatilden elde ettiği eşsiz deneyimden haz duyma beklentisiyle yolculuk yapan bir seyyah olarak tanımlamıştır. Bireye göre yeni bir destinasyonun diğerlerinin yerine tercih edilmesi, yeni bir uyarıcının harekete geçirilmesiyle mümkün olmaktadır. Bu bağlamda yenilik arayışı boyutuna yönelik yaratıc1 turizm önemli bir destinasyon pazarlamas1 stratejisi olabilecektir. Bireysel gelişime katk1 sağlamayı hedefleyen yerel kültürü ve yeniliği birleştiren yaratıcı turizm içeriği (yerel sanat, gece hayatı, etnik unsurlar ve yerel gastronomi) turistlerin artık daha merak uyandıran interaktif deneyimlere ilgi duymasıyla ortaya çıkmıştır. Duygular boyutu açısından bakıldığında turistler, yaşadıkları ve günlük ihtiyaçlarını giderdikleri yerin dışında farklı bir destinasyona seyahat ederek güzel zaman geçirme, rutin hayatın monotonluğundan bir süreliğine uzaklaşarak geçici olarak farklı bir karaktere bürünme veya farklı duygular içine girme davranışında bulunabilmektedirler. Duygular yaşanan bir olayın değerlendirilmesi sonucunda veya müşterinin kişisel düşüncelerinden kaynaklanarak ortaya çıkmaktadır. Deneyimleri destinasyonda yaşanan olumlu ya da olumsuz duygular şekillendirmektedir. Dolayısıyla destinasyon yöneticileri ve turizm operatörleri, tatil esnasında yaşanan olumlu duygular ile şekillenen hatırlanabilir destinasyon deneyiminin oluşması için çaba sergilemelidir. İstanbul, sahip olduğu üst yapı mimarisi ve yenilik fırsatı sunması bağlamında da duygu boyutunun tetikleneceği bir destinasyondur. Bu üç boyutun yanı sıra yerel kültür, destinasyondaki insanların misafirperverliği ve gastronomi de öne çıkan diğer boyutlardır. Bu bağlamda yerel kültürün ve gastronominin deneyimleneceği fursatlar turistlere sunulmalıdır. Ayrıca Türk turizmi kapsamın- 
da Türk insanının karakteristiği bağlamındaki misafirperverlik unsurları, yerel kültür dinamikleri ve mutfak kültürü öğeleri de tanıtım stratejilerinde göstergebilimsel olarak vurgulanmalıdır. Öte yandan, ulaşım ve fiyat-değer özelliklerinin etkisi diğerlerine oranla düşük çıkmıştır. Bu bağlamda destinasyonda uygulanan yeme-içme, konaklama, gezi vb. hizmet fiyatlarının gözden geçirilmesi gerekmektedir. Bu faktörlerin yanı sıra Antalya destinasyonunda çıkan fiziki coğrafya faktörünün destinasyon deneyimi bileşenleri içinde yer almadığı görülmüştür. İstanbul'da üst yapı estetiği boyutunun en önemli faktör olması unsuru İstanbul'un tarihi ve mimari yapısıyla ön plana çıktığını ve coğrafik karakteristik özelliklerinin geri planda kaldığını göstermektedir.

Antalya destinasyonu deneyimi modelinde İstanbul'un aksine fiziki coğrafya boyutu en önemli boyut olarak ortaya çıkmıştır. Bu bağlamda Antalya'nın iklimi, havası, manzarası ve sahip olduğu ekolojik alanlarının, turistler tarafından algilanan en önemli faktör olduğu söylenebilir. Antalya tanıtım video ve görsellerinde fiziki coğrafya öğelerinin daha çarpıcı hale getirilerek öne çıkarılması, söz konusu tabiat alanlarının tur güzergâhlarına eklenmesi, rehberlerin bu konuda ziyaretçileri bilgilendirici aktivitelerde yer alması tavsiye edilebilir. Daha geniş kapsamda düşünüldüğünde ise bölgesel turizm gelişim stratejisinde Antalya'nın tabiat özellikleri konusunda hassas, etkili ve sonuç odaklı yaklaşımlara yer verilmesi önerilebilir. Antalya'nın sahip olduğu iklim ve hava koşulları, doğal yapı, bitki örtüsü, ekolojik çeşitlilik ve tabiat gibi unsurlar turistlerin bölgede turizm ürün çeşitliliğinin artırılmasının ne denli önemli olduğunu bir kez daha ortaya koymuştur. Fiziki coğrafyanın yanı sıra Antalya'da misafirperverlik, duygular ve hizmet kalitesi de önemli boyutlar olarak ortaya çıkmıştır. Hizmet kalitesinin modelde önemli bir yer edinmesin de Antalya'da yer alan modern ve çoğunlukla her şey dahil konseptli olan konaklama tesislerinin rolünün olduğu söylenebilir. Bu boyut içinde yer alan servis kalitesi, personel ve kişiselleştirilmiş hizmetin varlığ konseptinin eleştirilerinin uzağında kalmaktadır. Ayrıca Antalya modeli içinde misafirperverlik boyutunun yer alması hizmet kalitesiyle de para- lel olarak ortaya çıkan bir sonuç olarak düşünülebilir. İstanbul destinasyon deneyimi modelinde ortaya çıkan ulaşım boyutu Antalya modelinde yer almamıştır. Çünkü ağırlıklı olarak paket turlarla gelen turistler, karşılayıcı acenteler ile transfer edilmektedir. Ayrıca yerel ulaşım kapsamında da turistlerin konaklama birimleri dışına çımayarak ulaşım deneyimlerini yaşama imkânları bulmamaları veya yerelde ulaşım birimlerinin yetersizliği gibi unsurlarda neden olarak gösterilebilir. Örneğin Antalya havalimanından şehrin belli başlı noktalarına doğru giden tramvay sistemi EXPO2016 ile birlikte yapılmıştır. Nitekim Avrupa'da Türkiye'nin rakibi olan İtalya, İspanya gibi ülkelerde turistler havalimanlarından otellerine kadar farklı ve uygun yerel ulaşım araçlarından yararlanabilmektedirler. Antalya içinde Perge antik şehrine gitmek isteyen bir turist ancak taksi kullanarak ulaşım sağlayabilir. Bu durumda bazen turistler fahiş ücretler ödemek ve destinasyonu da bu bağlamda değerlendirmek zorunda kalmaktadırlar. Bu bağlamda da destinasyon yöneticileri ulaşım faktörü üzerine eğilmelidirler. Üstyapı unsuru da Antalya'da ön plana çıkan faktörlerdendir ve bunun temel nedeni olarak, atmosferik deneyimden yararlanarak daha çok turist ağırlamayı hedefleyen otellerin, mimaride estetik öğelere önem vermesi, ilgi çekici ve görkemli tasarımlarla inşa edilmesi gösterilebilir.

Genel olarak değerlendirildiğinde araştırma sonuçlarına göre İstanbul yedi boyutta (yerel kültür, aktiviteler, üstyapı estetiği, gastronomi, fiyatdeğer, yenilik fırsatları, duygular) Antalya'dan daha olumlu ziyaretçi algısı elde etmiştir. Her iki destinasyona ait ortalamalar dikkate alındığında, ziyaretçilerin 'aktiviteler' ve 'altyapı' yeterliliğine ilişkin ifadelere katılım konusunda çekimser oldukları dikkat çekmektedir. Bu sonuç her iki destinasyonda turistlere sunulan aktivite ve etkinlikler ile altyapı olanakların gözden geçirilmesi gerektiğine işaret etmektedir. Bu sonuçtan hareketle, Antalya ve İstanbul'da turistik tabela ve işaretlemeler konusunda eksikliklerin tespit edilmesi önerilmektedir. Özellikle ziyaret noktalarına ev sahipliği yapan semtlerde bulunan yön ve işaret levhalarının yenilenmesi; söz konusu levhaların çeşitli milliyetlere mensup turistler tarafından kolay anlaşılacak düzeyde yabancı 
ibare ve açıklamalarla detaylandırılması; turist enformasyon ofislerinin daha sik aralıklarla kolay ulaşılabilir noktalarda konumlandırılması önerilmektedir. Ayrıca bu ofislerde ziyaretçilerle etkin iletişim sağlayacak düzeyde yabancı dil bilgisine sahip yeterli düzeyde turizm ve diksiyon eğitimi almış personelin istihdam edilmesi önerilmektedir. Bununla birlikte turistlerin destinasyon deneyimini zenginleştirecek, yerel kültürün daha yakından tanınmasına imkân verecek ve kültürler arası etkileşimi artıracak aktivitelerin organize edilmesi önerilebilir. Araştırma kapsamında analiz sonuçları İstanbul'un altyapı, hizmet kalitesi ve ulaşım, Antalya'nın ise duygular ve ekonomik değer özellikleri konularında Alman turistlere ilişkin algıların İngiliz ve Ruslara göre daha negatif yönlü olduğunu ortaya çıarmıştır. Bu sonucun, Almanların yüksek beklenti ve üst düzey kalite anlayışına sahip bir milliyet olduğu varsayımına paralel olarak geliştiği düşünülmektedir. Alman turistlerin destinasyonda deneyimlediği bileşenleri, kendi ülkesindeki nispeten daha yüksek kalite standartlarıyla kıyasladığ 1 ve bunun neticesinde altyapı, hizmet kalitesi, ulaşım, ekonomik değer gibi konularda daha hassas bir değerlendirme yaparak diğer milliyetlere göre daha negatif yönlü algı ortaya koymuş olabileceği düşünülmektedir. Bu araştırmadan elde edilen sonuçlar çerçevesinde görülmüştür ki her destinasyonun kendine has deneyim bileşenleri bulunmaktadır. Destinasyonlar, deneyim bileşenlerini keşfederek, güçlü oldukları boyutları göz önünde bulundurmalı ve özgün bir destinasyon kimliği yaratarak destinasyonun kendine has DNA yapıları üzerinden bir konumlandırma yaparak hedef pazarlarına yönelmelidirler. Ayrıca destinasyon deneyimi bileşenlerinde düşük çıkan boyutların ortaya çıkarılması ve gerekli eylem planlarının çizilmesi de turistlerin destinasyon deneyimlerini güçlendirmek açısından önemli fikirler sunacaktır. Unutulmaması gereken ise destinasyon deneyimi bileșenlerine yönelik yapılacak analizler ve hazırlanacak eylem planları çoklu turizm paydaşları eşliğinde gerçekleştirilmelidir. Aksi takdirde belirlenen öneriler realistik bir yaklaşımla ele alınmayacak ve eylem planı üzerinde kalacaktır.

\section{KAYNAKÇA}

Boorstin, D. (1964). The Image: A Guide to Pseudo-Events in America. Newyork: Harper.

Burkart, A. J. ve Medlik, S. (1992). Tourism, Past, Present and Future. Oxford: Butterworth-Heinemann Ltd.

Chew, J. (1987). Transport and Tourism in the Year 2000, Tourism Management, 8 (2): 83-85.

Chi, C. ve Qu, H. (2008). Examining the Structural Relationships of Destination Image, Tourist Satisfaction and Destination Loyalty: An Integrated Approach, Tourism Management, 29: 624-636.

Crompton, J. (1979). Motivations for Pleasure Vacation, Annals of Tourism Research, 408-424.

Crouch, G. I. (2011). Destination Competitiveness: An Analysis of Determinant Attributes, Journal of Travel Research, 50 (27): 27-45

Csikszentmihalyi, M. (1975). Beyond Boredom and Anxiety: The Experience of Play in Work and Games. San Francisco: Jossey-Bass Publishers.

Çetin, G. ve Bilgihan, A. (2014). Components of Cultural Tourists' Experiences in Destinations, Current Issues in Tourism, 19 (2): 1-18.

Driscoll, A., Lawson, R. ve Niven, B. (1994). Measuring Tourists' Destination Perceptions, Annals of Tourism Research, 21 (3): 499-511.

Dwyer, L. ve Kim, C. (2003). Destination Competitiveness: Determinants and Indicators, Current Issues in Tourism, 6 (5):369-414.

Dwyer, L., Mellor, R., Mistilis, N. ve Mules, T. (2000). Forecasting the Economic Impacts of Events and Conventions, Event Management, 6 (3): 175-191.

Edensor, T. (2001). Performing Tourism, Staging Tourism, Tourist Studies, 1: 59-81.

Fields, K. (2002). Demand for the Gastronomy Tourism Product: Motivational Factors. İçinde A. M. Hjalager ve G. Richards (Editörler), Tourism and Gastronomy (ss. 3650), Londra: Routledge.

Go, F. M. ve Govers, R. (2000). Integrated Quality Management for Tourist Destinations: A European Perspective on Achieving Competitiveness, Tourism Management, 21(1): 79-81.

Gunn, C. (1988). Tourism Planning. New York: Taylor \& Francis.

Huberty, C. J. ve Petoskey, M. D. (2000). Multivariate Analysis of Variance and Covariance. İçinde H. T. Brown (Editör), Handbook of Applied Multivariate Statistics and Mathematical Modeling. New York: Academic Press.

Inskeep, E. (1991). Tourism Planning: An Integrated and Sustainable Development Approach. New York: Van Nostrand Reinhold.

Ivanovic, M., Khunou, P. S., Reynish, N., Pawson, R., Tseane, L. ve Wassung, N. (2009). Tourism Development 1: Fresh Perspectives. Cape Town: Pearson Education and Prentice Hall.

Jang, S. ve Feng, R. (2007). Temporal Destination Revisit Intention: The Effects of Novelty Seeking and Satisfaction, Tourism Management, 28: 580-590. 
Kandampully, J. (2000). The Impact of Demand Fluctuation on the Quality of Service: a Tourism Industry Example, Managing Service Quality: An International Journal, 10 (1): $10-19$.

Kaul, R. N. (1985). Dynamics of Tourism: A Trilogy (Vol: 111). Transportation and Marketing, New Delhi: Sterling Publishers.

Khadaroo, J. ve Seetanah, B. (2008). The Role of Transport Infrastructure in International Tourism Development: A Gravity Model Approach, Tourism Management, 29: 831-840.

Kim, J. H. (2014). The Antecedents of Memorable Tourism Experiences: The Development of a Scale to Measure the Destination Attributes Associated with Memorable Experiences, Tourism Management, 44: 34-45.

Kivela, J. ve Crotts, J. (2005). Gastronomy Tourism: a Meaningful Travel Market Segment, Journal of Culinary Science and Technology, 4 (2-3): 39-55.

Kivela, J. ve Crotts, J. C. (2006). Tourism and Gastronomy: Gastronomy's Influence on How Tourists Experience a Destination, Journal of Hospitality and Tourism Research, 30 (3): 354-377.

Kozak, M. (2001). Comparative Assessment of Tourist Satisfaction with Destinations, Tourism Management, 22: 391-401.

Lagiewski, R. ve Zekan, B. (2006). Experiential Marketing of Tourism Destinations. http://scholarworks.rit.edu/other/633. Erişim tarihi: 22 Nisan 2015.

Lee, T. H. ve Crompton, J. (1992). Measuring Novelty Seeking in Tourism, Annals of Tourism Research, 19 (4): 732-751.

MacCannell, D. (1973). Staged Authenticity: Arrangements of Social Space in Tourist Settings, American Journal of Sociology, 79 (3): 589-603.

Machlis, G. ve Burch, W. (1983). Relations Between Strangers: Cycles of Structure and Meaning in Tourist Systems, Sociological Review, 31: 666-692.

Mannell, R. C., Larson, R. ve Zuzanek, J. (1998). Leisure States and Flow Experiences: Testing Perceived Freedom and Intrinsic Motivation Hypotheses, Journal of Leisure Research, 20: 289-304.

Mossberg, L. (2007). A Marketing Approach to the Tourist, Scandinavian Journal of Hospitality and Tourism, 7 (1): 5974.

Murphy, P., Pritchard, M. ve Smith, B. (2000). The Destination Product and its Impact on Traveller Perceptions, Tourism Management, 21: 43-52.

Neuhofer, B., Buhalis, D. ve Ladkin, A. (2012). Conceptualising Technology Enhanced Destination Experiences. Journal of Destination Marketing \& Management, 1 (1-2): 36-46.
Nunnally, J. C. (1978). Psychometric Theory. New York, NY: McGraw-Hill.

Oh, H., Fiore, A. ve Jeoung, M. (2007). Measuring Experience Economy Concepts: Tourism Aplications, Journal of Travel Research, 46 (2): 119-132.

Oral, S. ve Çelik, A. (2013). Türkiye'yi Ziyaret Eden Turistlerin Estetik Deneyimleri Üzerine Bir Araştırma, İşletme Araştırmaları Dergisi, 5 (4): 170-190.

Otto, J. ve Ritchie, J. (1996). The Service Experience in Tourism, Tourism Management, 17 (3): 165-174.

Page, S. ve Hall, M. (2003). Managing Urban Tourism: Themes in Tourism. London: Pearson Education Limited.

Pine, J. ve Gilmore, J. H. (1998). Welcome to the Experience Economy, Harvard Business Review, 76: 97-105.

Pine, J. ve Gilmore, J. H. (1999). İş Hayatı Bir Tiyatro. İstanbul: Boyner Yayınları.

Pine, J. ve Gilmore, J. (2000). Satisfaction, Sacrifice, Surprise: Three Small, Strategy and Leadership, 28 (1): 18-23.

Prentice, R. (2001). Experiential Cultural Tourism: Museums \& the Marketing of the New Romanticsm of Evoked Authenticity, Museum Management and Curatorship, 19 (1): 7-30.

Ritchie, J. ve Crouch, G. (2003). The Competitive Destination: A Sustainable Tourism Perspective. Cambridge, MA.: CABI Yayınları.

Sakai, M. (2006). Public Investment in Tourism Infrastructure. İçinde International Handbook on the Economics of Tourism (ss. 266-280), İngiltere: Edward Elgar Yayınları.

Schmitt, B. H. (1999). Experiential Marketing, Journal of Marketing Management, 15 (1-3): 53-67.

Shoukri, M. ve Edge, V. (1996). Statistical Methods for Health Sciences. CRC Press, Inc.

Stamboulis, Y. ve Skayannis, P. (2003). Innovation Strategies and Technology for Experience-Based Tourism, Tourism Management, 24: 35-43.

Tribe, J. ve Snaith, T. (1998). From SERVQUAL to HOLSAT: Holiday Satisfaction in Varadero, Tourism Management, 19 (1): 25-34.

Use place DNA to Define Your Destination's Core Identity, Destination Think, https://www.destinationthink.com/ use-place-dna-define-destinations-core-identity, Erişim tarihi: 17 Haziran 2017.

WTO (2007). A Practical Guide to Tourism. Madrid: World Tourism Organization Press.

Zhang, Q. Z. ve Chow, I. (2004). Application of ImportancePerformance Model in Tour Guides' Performance: Evidence from Mainland Chinese Outbound Visitors in Hong Kong, Tourism Management, 25 (1): 81-91. 

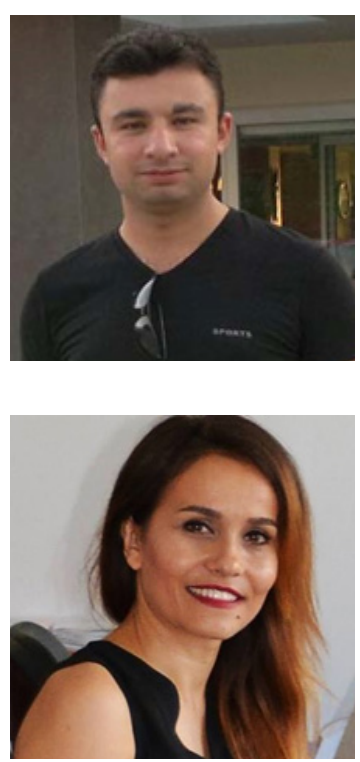

\section{İlker ŞAHIN}

Erciyes Üniversitesi, Nevşehir Turizm ve Otel İșletmeciliği Yüksekokulu'ndan mezun oldu (2008). 2013 yılında Kastamonu Üniversitesi Turizm Fakültesi'nde araştırma görevlisi olarak çalışmaya başladı. 2014 yılında lisansüstü eğitim için Akdeniz Üniversitesi'ne görevlendirildi. Yüksek lisans derecesini Akdeniz Üniversitesi Turizm İşletmeciliği ve Otelcilik ana bilim dalından (2016), alan yazar, aynı kurumda halen araştırma görevlisi olarak çalışmakta ve doktora eğitimine devam etmektedir. Temel çalışma alanları turizm pazarlaması, hatırlanabilir turizm, turist deneyimi, sürdürülebilir turizm ve turist rehberliğidir.

\section{Özlem GÜZEL}

Erciyes Üniversitesi, Nevşehir Turizm ve Otel İşletmeciliği Yüksekokulu'ndan mezun oldu (2004). Yüksek lisans derecesini Balıkesir Üniversitesi'nden Turizm İşletmeciliği ve Otelcilik dalından (2007), doktora derecesini de Süleyman Demirel Üniversitesi'nden İşletme dalından aldı (2012). 2007 yılında Muğla Sıtkı Koçman Üniversitesi'nde çalışmaya başladı. 2014 yılından beri Akdeniz Üniversitesi Turizm Fakültesinde öğretim üyesi olarak çalı̧̧maktadır. Doçentlik unvanını Turizm İşletmeciliği alanında aldı (2016). Temel çalışma alanları, turizm pazarlaması ve turist rehberliğidir. 